\title{
Comparison of cell adhesion molecule expression in cutaneous leucocytoclastic and lymphocytic vasculitis
}

\author{
N P Burrows, F A Molina, G Terenghi, P K Clark, D O Haskard, J M Polak, R R Jones
}

\begin{abstract}
Aims-To compare the expression of the cell adhesion molecules intercellular adhesion molecule-1 (ICAM-1), ELAM-1 (E-selectin), and vascular cell adhesion molecule-1 (VCAM-1) in cutaneous leucocytoclastic and lymphocytic vasculitis. Methods-Immunohistochemical analysis was performed on early lesional skin biopsy specimens of leucocytoclastic vasculitis $(n=14)$, lymphocytic vasculitis $(n=10)$, non-lesional skin $(n=12)$, and normal skin $(n=5)$. A standard immunoperoxidase technique was used to detect expression of ICAM-1, E-selectin, VCAM-1, and the cell markers CD11a, CD11b, CD11c, von Willebrand factor, CD3, CD68, and neutrophil elastase (NP57).
\end{abstract}

Results-Basal keratinocyte intercellular adhesion molecule-1 was expressed in eight $(80 \%)$ cases of lymphocytic and in only one $(7 \%)$ case of leucocytoclastic vasculitis, and not in non-lesional skin or control biopsy specimens from normal subjects. E-selectin was expressed on vascular endothelium in eight (57\%) cases of leucocytoclastic and in seven $(70 \%)$ cases of lymphocytic vasculitis. Endothelial vascular cell adhesion molecule-1 expression was seen in three $(21 \%)$ biopsy specimens of leucocytoclastic and five $(50 \%)$ of lymphocytic vasculitis.

There were increased numbers of cells in the dermal infiltrate stained for NP57, CD11b, and CD11c in leucocytoclastic compared with lymphocytic vasculitis (p $<0.001, \quad p=0.013, p=0.009$, respectively); immunoreactive positive cells for CD3 and CD11a were increased in lymphocytic compared with leucocytoclastic vasculitis $(p<0.001, p=0.011$, respectively).

Conclusions-These observations indicate that upregulation of adhesion molecule expression occurs in both leucocytoclastic and lymphocytic vasculitis. The different patterns of adhesion molecule expression in the two groups of vasculitis may reflect differences in the local release of cytokines. In particular, detection of intercellular adhesion molecule-1 expression by keratinocytes in lymphocytic vasculitis is consistent with an active role for mediators derived from $T$ lymphocytes in the pathogenesis of the lesion. (f Clin Pathol 1994;47:939-944)

Cutaneous vasculitis embraces a group of conditions with characteristic histological features involving small and medium sized blood vessels. Leucocytoclastic vasculitis, which may be associated with several clinical disorders, is characterised by a predominance of perivascular polymorphonuclear cells, nuclear dust, red cell extravasation, and deposition of fibrinoid material around cutaneous blood vessels. In contrast, lymphocytic vasculitis comprises a heterogeneous group of disorders characterised clinically by purpura and histologically by red cell extravasation in association with a perivascular mononuclear cell infiltrate. Controversy still exists about the pathogenesis of cutaneous vasculitis and it is not readily apparent why some patients exhibit a neutrophilic and others a lymphocytic infiltrate.

Several early studies of leucocytoclastic vasculitis have clearly shown the deposition of immunoglobulin and complement within vessel walls. ${ }^{12}$ In contrast, lesional deposits of immunoglobulin and complement are rarely found in patients with lymphocytic vasculitis ${ }^{3}$ and cell mediated immunological mechanisms have been implicated. ${ }^{4-8}$ Massa and $\mathrm{Su}^{9}$ felt that lymphocytic vasculitis is not a specific clinicopathological entity but a combination of histological features seen in a variety of clinical settings which include capillaritis, pityriasis lichenoides, toxic erythema, and drug induced purpura. It has also been suggested that the finding of perivascular lymphocytes in some cases of vasculitis is due to the biopsy specimen being taken at a relatively late stage in the development of a lesion. ${ }^{210}$

It is well recognised that cell adhesion molecules are important in the regulation of normal inflammatory responses. ${ }^{11}$ ICAM-1 (intercellular adhesion molecule-1) belongs to the immunoglobulin supergene family and is expressed on several different types of cells, including endothelial cells, activated lymphocytes, macrophages and activated keratinocytes. ${ }^{12}$ It is constitutively expressed on endothelial cells but it may be upregulated by interleukin-1, tumour necrosis factor, or interferon $\gamma .{ }^{1314}$ ICAM-1 binds the leucocyte $\beta_{2}$ integrins lymphocyte function associated antigen-1 (CD11a/CD18) and CD11b/ CD18 which mediate leucocyte-endothelial cell adhesion and the transendothelial 
migration of leucocytes into the tissues. ${ }^{115}$ VCAM-1 (vascular cell adhesion molecule-1) also belongs to the immunoglobulin supergene family. Expression of VCAM-1 on large vessel endothelial cells is induced by interleukin-1, tumour necrosis factor, or interleukin-4, ${ }^{16-18}$ whereas induction on microvascular endothelial cells is restricted to tumour necrosis factor in vitro. ${ }^{19}$ Expression of VCAM-1 in the skin is not restricted to endothelial cells but is also seen on some perivascular and dermal dendritic cells. ${ }^{20}$ VCAM-1 binds to VLA-4 (CD49d/CD29) found on lymphocytes, monocytes, eosinophils, and Langerhans' cells. ${ }^{21}$ Eselectin (endothelial leucocyte adhesion molecule-1) was first identified as an adhesion molecule for neutrophils. ${ }^{22}$ It is now recognised as also binding to eosinophils, basophils, monocytes, and a subpopulation of memory $\mathrm{T}$ cells (CD4+, CD45RO). ${ }^{23}{ }^{24}$ The neutrophil ligand for E-selectin has been identified as a carbohydrate, sialyl-Lewis $\mathrm{X},{ }^{25}$ whereas the cutaneous lymphocyte associated antigen (CLA), recognised by the monoclonal antibody HECA-452, is the ligand present on memory $\mathrm{T}$ cells. ${ }^{26}$ E-selectin is minimally expressed on unstimulated endothelial cells but is induced by interleukin-1 or tumour necrosis factor, but not directly by interferon $\gamma$ or interleukin- $4 .^{1827}$

There is evidence that the patterns of cell adhesion molecule expression may reflect the nature of the leucocyte infiltrate present in different forms of cutaneous inflammation. ${ }^{20}$ To throw further light on the pathogenesis of vasculitis, we therefore investigated whether leucocytoclastic and lymphocytic vasculitis are associated with differential expression of these cell adhesion molecules.

\section{Methods}

Hospital ethical committee approval was obtained to perform lesional and, where possible, site matched non-lesional elliptical biopsies in patients with cutaneous vasculitis. Site matched skin biopsy specimens were also taken from five age and sex matched healthy volunteers. The biopsies were performed under $2 \%$ lignocaine anaesthetic injected into the periphery of the area to be excised.

The skin specimens were bisected and one half was fixed in formalin and paraffin wax embedded for histological examination. The other half was immediately fixed for immunohistochemistry by immersion in Zamboni's fluid for six hours at room temperature, then transferred into a $0 \cdot 1 \mathrm{M}$ phosphate buffered saline (PBS, $\mathrm{pH}=7 \cdot 2$ ) containing $15 \%$ sucrose and $0 \cdot 1 \%$ sodium azide. Frozen sections $(10 \mu \mathrm{m})$ were cut, collected onto polyL-lysine coated glass slides, and left to dry at room temperature for one hour before being immunostained.

Twenty four patients with active cutaneous vasculitis were recruited from the dermatology outpatient department. The patients with vasculitis were subdivided, according to established histological criteria, into leucocy-
Table 1 Clinicopathological diagnoses

\begin{tabular}{ll}
\hline $\begin{array}{l}\text { Leucocytoclastic } \\
\text { vasculitis }(n=14)\end{array}$ & $\begin{array}{l}\text { Lymphocytic } \\
\text { vasculitis }(n=10)\end{array}$ \\
\hline $\begin{array}{l}\text { Urticarial vasculitis }(\mathrm{n}=7) \\
\text { Cryoglobulinaemia }(\mathrm{n}=2)\end{array}$ & $\begin{array}{l}\text { Capillaritis }(\mathrm{n}=6) \\
\text { Pityriasis lichenoides } \\
\text { chronoch Schönlein purpura }(\mathrm{n}=1)\end{array}$ \\
$\begin{array}{l}\text { Drugs }(\mathrm{n}=1) \\
\text { Idiopathic }(\mathrm{n}=2)\end{array}$ & $\begin{array}{l}\text { Idiopathic }(\mathrm{n}=3) \\
\end{array}$ \\
\hline
\end{tabular}

toclastic or lymphocytic vasculitis (table 1$){ }^{28}$

The antibodies used for staining are listed in table 2. Sections were stained using the three-step peroxidase-antiperoxidase (PAP) immunohistochemical method. ${ }^{29}$ Endogenous peroxidases were inhibited by soaking the sections in $0.3 \%$ hydrogen peroxide in methanol for 15 minutes. Diaminobenzidine was used as a substrate to visualise von Willebrand factor, ICAM-1, E-selectin, and VCAM-1; the sections were counterstained with Mayer's haematoxylin. To visualise leucocyte markers and integrin expression, the peroxidase was developed according to the glucose oxidase/nickel enhancement reaction. ${ }^{30}$ Negative controls were stained by omission of the primary antibody.

Two sections from each biopsy specimen were stained and analysed for expression of ICAM-1, E-selectin, VCAM-1, and von Willebrand factor. The numbers of immunoreactive cells within the dermal infiltrate were manually counted in six random fields $(\times 40$ magnification, within a $1 \mathrm{~mm}^{2}$ grid) from two sections per biopsy specimen stained for CD11a, CD11b, CD11c, CD3, NP57, and CD68. The results were then averaged for each group.

The expressions of antigens (excluding NP57 staining) were analysed separately using analysis of variance. The subjects were treated as a random factor, the condition (control, lymphocytic, and leucocytoclastic vasculitis) as a between-subjects factor and the lesion state (lesional or non-lesional) as a withinsubjects factor. The residuals were checked for normal distribution using the ShapiroFrancia W test and the data were log transformed when necessary to produce normality. When log data were used, the difference between groups was presented as a ratio of the geometric means. It was necessary to compare NP57 staining using the Mann-Whitney U

Table 2 Primary antibodies used for immunohistochemistry

\begin{tabular}{lll}
\hline Antibody & Antigen & Reference \\
\hline 6.5B5 & ICAM-1 & 36 \\
1.4C3 & VCAM-1 & 36 \\
1.2B6 & E-selectin (ELAM-1) & 36 \\
MHM24 & CD11a & $37^{\star}$ \\
44 & CD11b & $38 \dagger$ \\
3.9 & CD11c & $39 \dagger$ \\
A542 & CD3 (pan T cell) & $40^{\star}$ \\
NP57 & Neutrophil elastase & $41^{\star}$ \\
EBM11 & CD68 (mononuclear phagocytes) & $42^{\star}$ \\
A082 & Von Willebrand factor & $43^{\star}$ \\
\hline
\end{tabular}

* Purchased from Dakopatts.

†A kind gift from Dr Nancy Hogg, Imperial Cancer Research Fund, London. 
Table 3 Numbers of cells stained positively for leucocyte integrins and cell markers in lesional and control biopsy specimens

\begin{tabular}{lllll}
\hline & \multicolumn{2}{l}{$\begin{array}{l}\text { Mean number of } \\
\text { immunoreactive positive cells with 95\% confidence intervals }\end{array}$} & \\
\cline { 2 - 5 } & $\begin{array}{l}\text { (I) Leucocytoclastic } \\
\text { vasculitis }(n=4)\end{array}$ & $\begin{array}{l}\text { (II) Lymphocytic } \\
\text { vasculitis }(n=10)\end{array}$ & $\begin{array}{l}\text { (III) Controlt } \\
(n=17)\end{array}$ & $\begin{array}{l}\text { P Value } \\
\text { between } \\
\text { I and II }\end{array}$ \\
\hline CD11a & $114(85-152)$ & $213(147-308)$ & $11(7-16)$ & 0.01 \\
CD11b & $21(11-39)$ & $6(3-13)$ & $1(0-3)$ & 0.013 \\
CD11c & $112(76-166)$ & $47(28-79)$ & $12(6-21)$ & 0.009 \\
CD3 & $44(30-65)$ & $242(148-396)$ & $18(10-33)$ & $<0.001$ \\
CD68 & $113(83-153)$ & $106(72-154)$ & $27(18-42)$ & 0.79 \\
NP57 & $245(165-311)$ & $6(1-12)$ & 0 & $<0.001$ \\
\hline
\end{tabular}

* Confidence intervals and $p$ values were derived from analysis of variance on $\log$ transformed data apart from NP57 which was compared using the Mann-Whitney U test and is therefore data apart from NP57 which

$\dagger$ Included specimens from normal individuals and non-lesional skin from patients with vasculitis.
$\mathrm{CD} 3+, \mathrm{NP} 57+, \mathrm{CD} 68+$ and $\beta_{2}$ leucocyte integrin positive cells was seen in all lesional biopsy specimens compared with those from controls. Table 3 shows that there was an increase in $\mathrm{NP} 57+, \mathrm{CD} 11 \mathrm{~b}+$, and CD11c+ cells in leucocytoclastic compared with lymphocytic vasculitis $(\mathrm{p}<0.001, \mathrm{p}=0.013, \mathrm{p}=$ 0.009 , respectively), whereas CD11a + and CD3 + cells were increased in lymphocytic vasculitis $(p=0.01, p<0.001$, respectively). There was no significant difference in the numbers of CD68 + cells between the two vasculitic groups $(p=0 \cdot 79)$.

ICAM-1 was expressed constitutively on endothelial cells in control biopsy specimens, precluding meaningful comparisons between lymphocytic and leucocytoclastic vasculitis. Keratinocyte ICAM-1 expression was absent in control biopsy specimens, and the proportion of specimens with detectable keratinocyte staining for ICAM-1 was significantly increased in lymphocytic vasculitis (eight of $10,80 \%$ ) compared with leucocytoclastic vasculitis (one of 14,7\%), $p=0.0013$ (table 4). This ICAM-1 staining was almost exclusively confined to basal keratinocytes (fig 1A) and was seen close to the sites of CD1 1a (lymphocyte function associated antigen-1) positive cells, either in the upper dermis or within the epidermis (fig 1B). Greater numbers of ICAM-1 positive dermal dendritic cells were seen in lymphocytic vasculitis, although the number of positive biopsy specimens involved were too small for statistical comparisons.

E-selectin expression (figs $2 \mathrm{~A}$ and $\mathrm{B}$ ) was not present in control skin specimens but was seen in postcapillary venules in both leucocytoclastic (eight cases, 57\%) and lymphocytic vasculitis (seven cases, 70\%) (table 4).

VCAM-1 expression, which was absent in control biopsy specimens, was more frequently observed on endothelial cells in

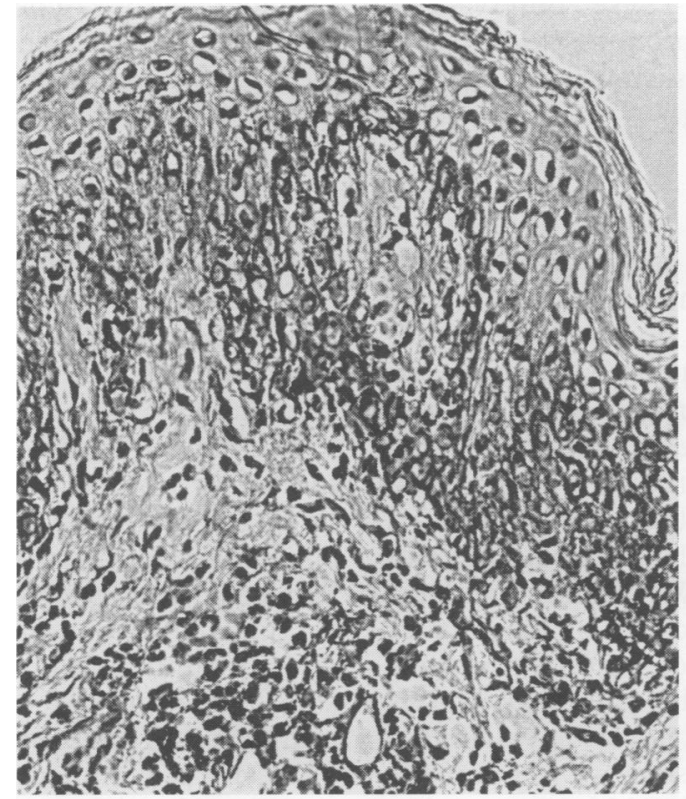

(A)

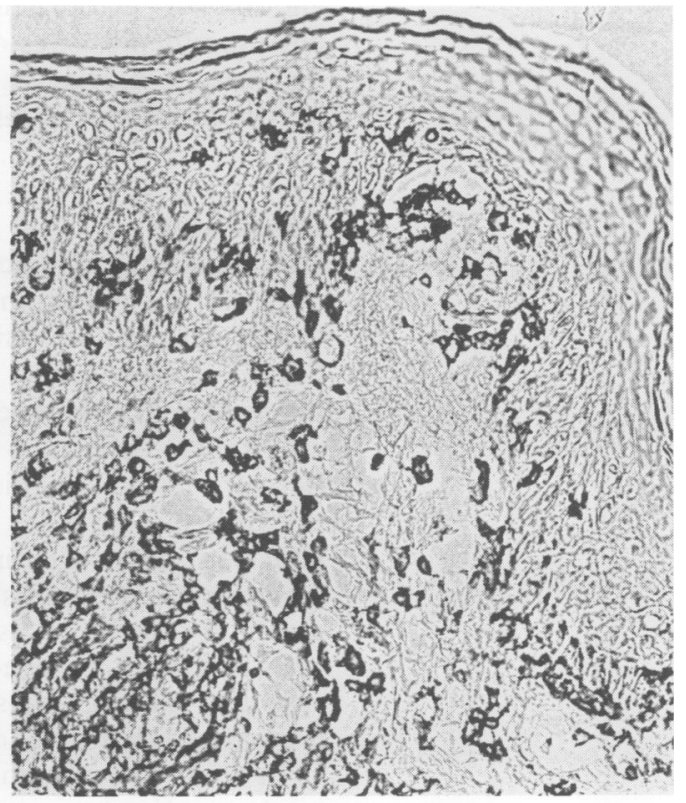

(B)

Figure 1 Lymphocytic vasculitis. (A) Strong ICAM-1 expression confined to basal keratinocytes (immunoperoxidase); (B) same biopsy specimen as in fig $1 A$ showing CD11 a (lymphocyte function associated antigen-1) positive cells in the upper dermis and epidermis (immunoperoxidase). 


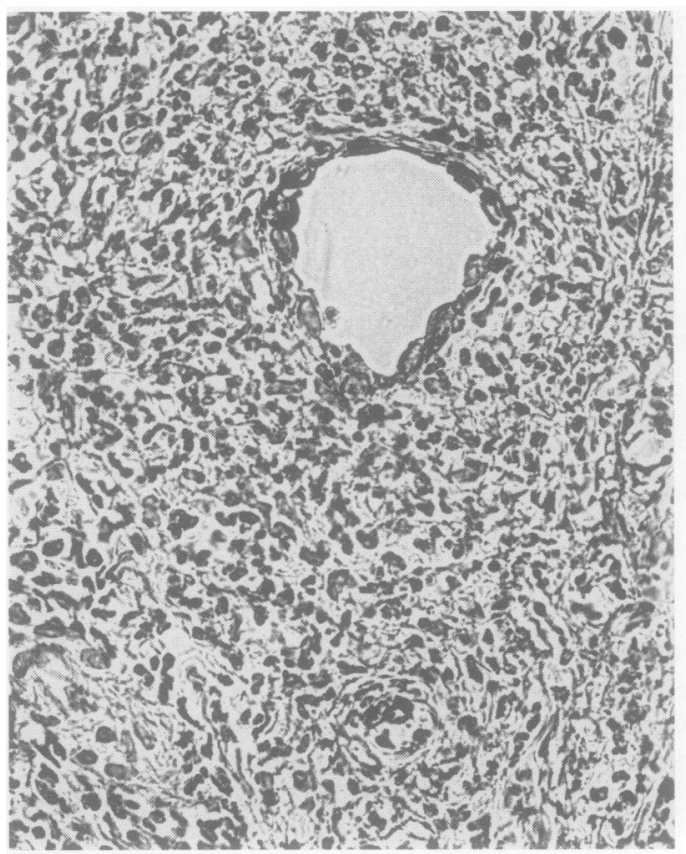

(A)

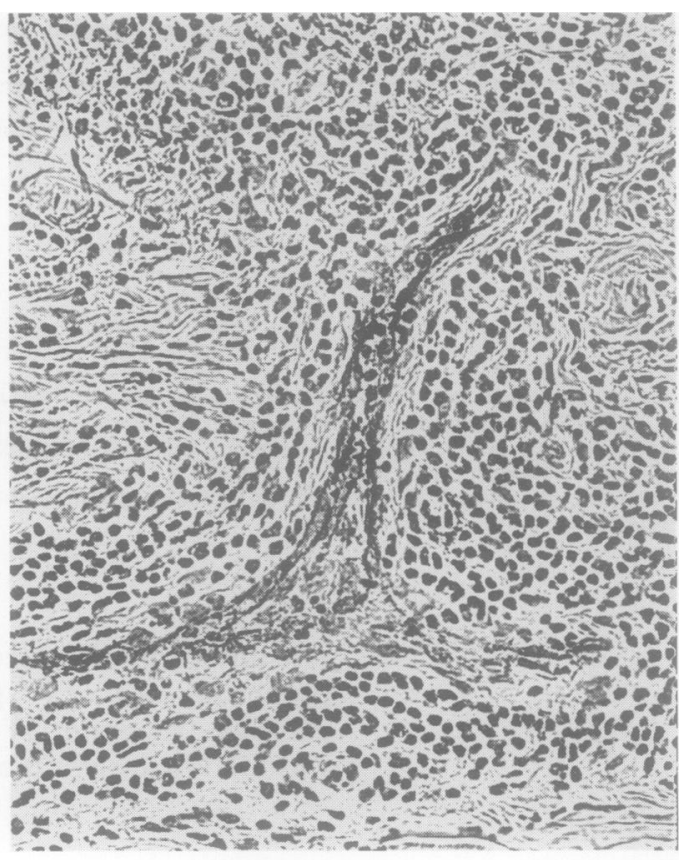

(B)

Figure 2 E-selectin staining confined to vascular endothelial cells. (A) Leucocytoclastic vasculitis (immunoperoxidase); (B) lymphocytic vasculitis (immunoperoxidase).

lymphocytic (five cases, 50\%) than leucocytoclastic vasculitis (three cases, $21 \%$ ), although this was not clinically important (table 4). As with ICAM-1, VCAM-1 immunoreactive dermal dendritic cells were more pronounced in lymphocytic compared with leucocytoclastic vasculitis, although the number of positive biopsy specimens were too small for statistical analysis.

Reduced or absent staining of all three endothelial adhesion molecules was seen within small areas of many lesional biopsy specimens. This was associated with a diffuse, weak perivascular staining by von Willebrand factor, suggesting antigen loss from the endothelial cytoplasm. These observations corresponded to sites of pronounced fibrinoid necrosis of blood vessels shown by haematoxylin and eosin staining.

\section{Discussion}

The pathophysiological mechanisms which underlie the development of cutaneous vasculitic lesions are still poorly understood. Some of the events may be common to inflammatory responses in general, but others are likely to determine the specific characteristics of a lesion. In this study we investigated the presence of three cell cytokine mediated adhesion molecules in leucocytoclastic and lymphocytic vasculitis. We found that lymphocytic vasculitis is associated, in most cases, with a pattern of adhesion molecule expression that distinguishes the pathology of this lesion from that of leucocytoclastic vasculitis.

In contrast to lesional skin, we were unable to detect E-selectin or VCAM-1 expression on blood vessels in biopsy specimens taken from non-lesional skin, indicating that endothelial activation occurs in both forms of vasculitis. Judging from in vitro experiments, the likely cytokines involved are either interleukin-1 or tumour necrosis factor, ${ }^{27}$ which could be released from a number of cells in the vicinity of the blood vessel, including macrophages, lymphocytes, keratinocytes, smooth muscle cells, and endothelial cells themselves. ${ }^{31}$

E-selectin was detected on endothelium of lesional skin in eight of 14 cases of leucocytoclastic vasculitis and in seven of 10 cases of lymphocytic vasculitis. The absence of $\mathrm{E}$ selectin staining in six of the leucocytoclastic biopsy specimens may in part be related to endothelial injury as four showed pronounced fibrinoid necrosis. The varying ages of the vasculitic lesions are also likely to be important, although whenever possible early (less than 24 hours' duration) lesions were biopsied. Eselectin is dependent on gene transcription and de novo protein synthesis and it is possible that the biopsy specimens might have been taken at a time point preceding E-selectin expression. More likely, however, E-selectin expression may have been missed as it is seen maximally two to four hours after cytokine stimulation. $^{32}$

Endothelial VCAM-1 expression was seen in three of 14 cases of leucocytoclastic vasculitis and in five of 10 cases of lymphocytic vasculitis. Although there was no difference between leucocytoclastic and lymphocytic vasculitis in the expression of VCAM-1 by endothelium, endothelial VCAM-1 expression tended to be associated with greater numbers of $T$ cells in the tissues, implicating VCAM-1 in lymphocyte recruitment.

Although both leucocytoclastic and lymphocytic vasculitis were characterised by endothelial expression of E-selectin, the two forms of lesion could largely be distinguished 
by the presence or absence of ICAM-1 expression by keratinocytes. Previous studies have shown that expression of ICAM-1 by keratinocytes is a feature of $\mathrm{T}$ lymphocyte mediated responses ${ }^{203334}$ and is not an inevitable feature of cutaneous inflammation. ${ }^{20}$ Our observations are therefore consistent with the lymphocytes emigrating into the tissues in lymphocytic vasculitis and playing an active part in the evolution of the lesions, perhaps by responding to antigen. Further studies examining cell surface markers of $T$ cell activation and the presence of $T$ cell derived cytokines, such as interferon $\gamma$, which are known to induce ICAM-1 expression by keratinocytes, ${ }^{1435}$ should throw further light on this matter.

Leucocytoclastic vasculitis, by definition, exhibits a perivascular neutrophil infiltrate and it was therefore anticipated that neutrophil elastase (NP57), CD11b, and CD11c would be found in the dermal infiltrate. Likewise, the inflammatory cells in lymphocytic vasculitis stained positively for $\mathrm{CD} 3$ and CD11a. These results reflect cell lineage and no inference can be drawn from this study regarding their role in cutaneous vasculitis.

In conclusion, this study has shown that endothelial cell activation occurs in both leucocytoclastic and lymphocytic vasculitis, as demonstrated by the presence of E-selectin expression. Keratinocyte expression of ICAM-1 was also more common in lymphocytic vasculitis, suggesting an active role for $T$ cells in the pathogenesis of this form of vasculitic lesion.

NPB was supported by a grant from North West Thames Locally Organised Research Scheme. FAM was in receipt of a grant of the programma nacional de becas de formación de personal investigador en el extranjero from the Ministerio de Educación y Ciencia, Spain.

1 Braverman IM, Yen A. Demonstration of immune complexes in spontaneous and histamine-induced lesions plexes in spontaneous and histamine-induced lesions and in normal skin of patients with leukoc

2 Gower RG, Sams WM, Thorne EG, Kohler PF, Claman HN. Leukocytoclastic vasculitis: sequential appearance of immunoreactants and cellular changes in serial biopsies. $\mathcal{F}$ Invest Dermatol 1977;69:477-84.

3 Smoller BR, McNutt NS, Contreras F. The natural history of vasculitis. What the histology tells us about the pathogenesis. Arch Dermatol 1990;126:84-9.

4 Klug $\mathrm{H}$, Haustein U-F. Ultrastructure of macrophagelymphocyte interaction in purpura pigmentosa progressiva. Dermatologica 1976;153:209-17.

5 Fauci AS, Haynes BF. The spectrum of vasculitis. Clinical, pathologic, immunologic, and therapeutic conClinical, pathologic, immunologic, and therape

6 Savel PH, Perroud A-M, Levy-Klotz B, Morel P. Vasculite eucocytoclasique et lymphocytaire des petits vaisseaux cutanés. Ann Dermatol Venereol 1982;109:503-14

7 Aiba S, Tagami H. Immunohistologic studies in Schamberg's disease. Evidence for cellular immune reaction in lesional skin. Arch Dermatol 1988;124:1058-62.

8 Simon $M$, Heese A, Götz A. Immunopathological investigations in purpura pig

9 Massa MC, Su WPD. Lymphocytic vasculitis: is it a specific clinicopathological entity? $\mathcal{f}$ Cut Pathol 1984;11: 132-9.

10 Zax RH, Hodge SJ, Callen JP. Cutaneous leukocytoclastic vasculitis. Serial histopathologic evaluation demonstrates the dynamic nature of the infiltrate. Arch Dermatol 1990;126:69-72.

11 Springer TA. Adhesion receptors of the immune system Nature 1990;346:425-34.

12 Dustin ML, Rothlein R, Bhan AK, Dinarello CA, Springer TA. Induction by IL 1 and interferon- $\gamma$ : tissue distribution, biochemistry, and function of a natural adherence molecule (ICAM-1). f Immunol 1986;137:245-54.

13 Dustin ML, Springer TA. Lymphocyte function-associated antigen-1 (LFA-1) interaction with inter-cellular adhesion molecule-1 (ICAM-1) is one of at least three mechanisms for lymphocyte adhesion to cultured mechanisms for lymphocyte adhesion to

14 Dustin ML, Singer KH, Tuck DT, Springer TA. Adhesion of $\mathrm{T}$ lymphoblasts to epidermal keratinocyte is regulated by interferon- $\gamma$ and is mediated by intercellular adhesion molecule 1 (ICAM-1). F Exp Med 1988; 167:1323-40

15 Smith CW, Rothlein R, Hughes B, Mariscalco $M$, Schmalstieg F, Anderson DC. Recognition of an endothelial determinant for CD18-dependent neutrophil adherence and transendothelial migration. 7 Clin Invest 1988;82:1746-56.

16 Osborn L, Hession C, Tizard R, Vassallo C, Luhowskyj S, Chi-Roso G, et al. Direct expression cloning of vascula cell adhesion molecule 1 , a cytokine-induced endothelial protein that binds to lymphocytes. Cell 1989;59: 1203-11.

17 Rice GE, Bevilacqua MP. An inducible endothelial cel surface glycoprotein mediates melanoma adhesion. Science 1989;246:1303-6.

18 Thornhill $\mathrm{MH}$, Haskard DO. IL-4 regulates cell activation by IL-1, tumour necrosis factor or IFN- $\gamma$. $f$ Immunol 1990;145:865-72.

19 Swerlick RA, Lee KH, Li LJ, Sepp NT, Caughman SW, Lawley TJ. Regulation of vascular cell adhesion molecule 1 on human dermal microvascular endothelial cells. f Immunol 1992;149:698-705.

20 Norris PG, Poston RN, Thomas ST, Thornhill M, Hawk J, Haskard DO. The expression of endothelial adhesion molecule-1 (ELAM-1), intercellular adhesion molecule(ICAM-1) and vascular adhesion molecule-1 (VCAM1) in experimental cutaneous inflammation: a comparison of ultraviolet B erythema and delayed type hypersensitivity. F Invest Dermatol 1991;96:763-70.

21 Elices MJ, Osborn L, Takada Y, Crouse C, Luhowskyj S, Hemler ME, et al. VCAM-1 on activated endothelium interacts with the leukocyte integrin VLA-4 at a site distinct from the VLA-4/fibronectin binding site. Cell 1990; 60:577-84

22 Bevilacqua MP, Pober JS, Mendrick DL, Cotran RS, Gimbrone MA. Identification of an inducible endothelial-leukocyte adhesion molecule. Proc Natl Acad Sci USA 1987;84:9238-42.

23 Picker LJ, Kishimoto TK, Smith CW, Warnock RA, Butcher EC. ELAM-1 is an adhesion molecule for skin homing T cells. Nature 1991;349:796-9.

24 Shimizu Y, Shaw S, Graber N, Gopal TV, Horgan KJ, van Seventer GA, et al. Activation-independent binding of human memory $\mathrm{T}$ cells to adhesion molecule ELAM-1. Nature 1991;349:799-802.

25 Phillips ML, Nudelman E, Gaeta FCA, Perez M, Singhal AK, Hakomori S-I, et al. ELAM-1 mediates cell adhesion by recognition of a carbohydrate ligand, Sialyl-L $e^{x}$ Science 1990;250:1130-2.

26 Berg EL, Yoshino T, Rott LS, Robinson MK, Warnock RA, Kishimoto TK, et al. The cutaneous lymphocyt antigen is a skin lymphocyte homing receptor for the vascular lectin endothelial cell-leukocyte adhesion molecule 1. F Exp Med 1991;174:1461-6.

27 Pober JS, Bevilacqua MP, Mendrick DL, Lapierre LA, Fiers W, Gimbrone MA. Two distinct monokines: interleukin 1 and tumour necrosis factor, each independently induce biosynthesis and transient expression of the same antigen on the surface of cultured human vascular antigen on the surface of cultured human

28 Copeman PWM, Ryan TJ. The problems of classification of cutaneous angiitis with reference to histopathology and pathogenesis. Br ₹ Dermatol 1970;82(suppl 5):2-14

29 Sternberger LA. The unlabelled antibody peroxidaseantiperoxidase (PAP) method. In: Immunocytochemistry. 2nd edn. New York: John Wiley, 1979:104-69.

$30 \mathrm{Shu}$ S, Ju G, Fan L. The glucose oxidase-DAB-nicke enhancement method in peroxidase histochemistry of the nervous system. Neurosci Lett 1988;85:169-71.

31 Haskard DO. Cytokines, growth factors and interferons. In: LeRoy EC, ed. Systemic vasculitis. New York: Marcel Dekker Inc, 1992:223-47.

32 Bevilacqua MP, Stengelin S, Gimbrone MA, Seed B. Endothelial leukocyte adhesion molecule 1: an inducible receptor for neutrophils related to complement regulatory proteins and lectins. Science 1989;243:1160-5.

33 Lewis RE, Buchsbaum M, Whitaker D, Murphy GF. Intercellular adhesion molecule expression in the evolving human cutaneous delayed hypersensitivity reaction. f Invest Dermatol 1989;93:672-7

34 Singer KH, Tuck DT, Sampson HA, Hall RP. Epidermal keratinocytes express the adhesion molecule intercellular adhesion molecule- 1 in inflammatory dermatoses. $f$ Invest Dermatol 1989;92:746-50.

35 Griffiths CE, Voorhees J, Nickoloff BJ. Characterization of intercellular adhesion molecule-1 and HI A-DR expression in normal and inflamed skin: modulation by expression in normal and inflamed skin: modulation by factor. $₹ \mathrm{Am}$ Acad Dermatol 1989;20:61 7-29.

36 Wellicome SM. Thornhill MH, Pitzalis C, Thomas DS Lanchbury JSS, Panayi GS, et al. A monoclonal antibody that detects a novel antigen on endothelial cells that is induced by tumour necrosis factor, IL-1, or lipopolysaccharide. F Immunol 1990;144:2558-65.

37 Hildreth JEK, Gotch FM, Hildreth PDK, McMichael AJ. A human lymphocyte-associated antigen involved in cellmediated lympholysis. Eur $f$ Immunol 1983;13:202-8.

38 Malhotra V, Hogg N, Sim RB. Ligand binding by the 
p150,95 antigen of U937 monocytic cells: properties in common with complement receptor type 3 (CR3). Eur $\mathcal{F}$ Immunol 1986;16:1117-23.

39 Hogg N, Takacs L, Palmer DG, Selvendran Y, Allen C. The p150,95 molecule is a marker of human mononuclear phagocytes: comparison with expression of class II molecules. Eur f Immunol 1986;16:240-8.

40 Erber WN, Pinching AJ, Mason DY. Immunocytochemical detection of T cell and B cell populations in routine blood smears. Lancet 1984;i:1042-5.
41 Pulford KAF, Erber WN, Crick JA, Olsson I, Micklem KJ, Gatter KC, et al. Use of monoclonal antibody agains neutrophil elastase in normal and leukaemic myeloid cells. F Clin Pathol 1988;41:853-60.

42 Kelly PMA, Bliss E, Morton JA, Burns J, McGee JO'D. Monoclonal antibody EBM/11: high cellular specificity for human macrophages. $\mathcal{F}$ Clin Pathol 1988;41:510-5.

43 Sehested $M$, Hou-Jensen $K$. Factor VIII-related antigen as an endothelial cell marker in benign and malignant diseases. Virchows Arch (Pathol Anat) 1981;391:217-25. 